JRIT\&L

10,2

Received 30 June 2017

Revised 11 August 2017

Accepted 24 August 2017

\section{Entrepreneurship students distilled their learning experience through reflective learning log}

\author{
Khar Kheng Yeoh \\ School of Business Management, College of Business, University Utara Malaysia, \\ Changlun, Malaysia
}

\begin{abstract}
Purpose - This Scholarship of Teaching and Learning research is a part of the larger study grant to analyze written reflections through learning log among the third and final year students undertaking BPME 3073 Entrepreneurship module in University Utara Malaysia (UUM). The paper aims to discuss these issues.

Design/methodology/approach - The data collection techniques are researcher-directed textual data through reflective learning log, taken from 140 students from three classes. A thematic approach was utilized to present the reflections of the students and all data were recorded in a verbatim format.

Findings - The findings show that most students have never written a reflective log or essay in the formative assessment. As a consequence, they had difficulty in writing the reflection when being requested to do so. A total 75 (approximately 55 percent) of the reflective logs were identified as level 1 (from 1 to 5 percent) in which reflections were simply written in a descriptive manner, resulted in a balance of 61 learning logs being utilized for further analysis. The students' reflections on their entrepreneurship's experience systematically categorize into four different themes comprised of: the nature of entrepreneurship module, entrepreneurial characteristics, opportunity recognition, and creativity and innovation.

Research limitations/implications - As for the limitation of the study, it is important to not to underestimate the challenges of introducing a grade assessment that most of them are not familiar with in their university academic journey. Students need guidance, assurance and confidence writing something that require personal opinion, own thinking, sensitive and personal nature of narration. For most students as found out in this study, self-confessional writing is hard to come by (they dare not attempt it in the first place), only a handful appreciating the writing start with "I," "me" as first person. More research in this study should be conducted across the university to gauge the response from the students to see if the result of this study is only applicable to this group of students or to this discipline of studies. The researchers would also like to recommend for future studies which take the form of a longitudinal study of similar kind to examine the problems and challenges with regards to promoting learning reflection at the undergraduate level.

Practical implications - Based on the result of the 61 students who had demonstrated an ability in reflective writing, it is suggested that perhaps the university should consider offering coursework that contains a component of reflective writing as part of the assessment. As such, if this is implemented, students of such ability like the one in this sample group would have been benefitted from such assessment which look at reflective ability (Greene, 2014) and which they were allowed to form a broader perspective in relation to the module undertaken. This in turns will foster the growth of reflective ability which is recognized as a learned behavior (Gustafson and Bennett, 1999). In addition, for the future exercise of this reflective learning log, the researcher opined that we should encourage our students to engage with another student (e.g. close friend) in a way that encourages talking with, questioning, or confronting, helped the reflective process by placing the learner in a safe environment in which self-revelation can take place. In addition, students were able to distance themselves from their actions, ideas and beliefs, by holding them up for scrutiny in the company of a peer with whom they are willing to take such risks (Hatton and Smith, 1995).
\end{abstract}

Originality/value - The results of this research have strongly suggested the need to urgently develop among the students the skills in writing reflectively as they go through the process of higher education which

(c) Khar Kheng Yeoh. Published in the Journal of Research in Innovative Teaching \& Learning. Published by Emerald Publishing Limited. This article is published under the Creative Commons Attribution (CC BY 4.0) licence. Anyone may reproduce, distribute, translate and create derivative works of this article (for both commercial and non-commercial purposes), subject to full attribution to the original publication and authors. The full terms of this licence may be seen at http://creativecommons.org/licences/by/4.0/legalcode

The author would like to express his gratitude to Unit of Teaching and Learning Center (UTLC), University Utara Malaysia for their support. This study received financial support from Scholarship of Teaching and Learning (SoTL) under Grant - Kod So 13396.
Journal of Research in Innovative Teaching \& Learning Vol. 10 No. 2 ,
pp. $126-142$ Emerald Publishing Limite 2397-7604 DOI 10.1108/JRIT-06-2017-0012 
is useful in molding their future professional and entrepreneurial behavior as when they entered the job Entrepreneurship market which requires a critical reasoning ability.

Keywords Entrepreneurship, Thematic analysis, Critical reflection, Action research, Critical thinking,

Reflective learning log

Paper type Research paper

\section{Introduction}

Entrepreneurship has always been conceptualized as a process of discovering an opportunity, sourcing and manipulate resources, planning, and execution intelligence. An entrepreneur knows all the parts and knows how to match and fit all those resources together. The above narration signifies that a process is quite predictable, but in reality, the nature of entrepreneurial activities (to undertake) is not predictable at all. Greene (2014) proposed a portfolio of four complementary techniques for teaching entrepreneurship as a method, not as a process. They are: businesses start-up, reality-grounded simulations and gamification, design-oriented learning, and reflective practice.

Each method requires learners to extend beyond the process-based paradigm of knowing, analyzing, and talking, instead positioning the learners to create, apply and act (Greene, 2014). In this Scholarship of Teaching and Learning (SoTL) study, the researcher adopts the reflective practice as a method for teaching entrepreneurship and the toolkit used is reflective learning log. Given its importance, reflective skills have now being recognized as an important proficiency among the professionals and being treated as a good source for critical thinking development, enhancing self-monitoring as well as leading to one having developed good reasoning skills. Furthermore, reflective exercise has also become a vital component for most professional degree programs, namely nursing, teaching as well as many business capstone courses that require final year students to recap and reflect before the end of their university's tenure (Chalk and Hardbattle, 2007).

Reflection is a significant process by which knowledge is derived from experience. When reflecting, one considers an experience that has happened and tries to understand or explain it, which often leads to insight and deep learning - or ideas to test on new experiences. Reflection is particularly important for puzzling experiences, operating under conditions of high ambiguity, and problem solving. As a result, it should not be a surprise that reflection is a pivotal component of entrepreneurship education and also a way of practicing entrepreneurship.

In this study, the researchers aspire the students in BPME 3073 Entrepreneurship to develop a strong sense of awareness and appreciation of reflecting by looking at what they are doing/learning now in entrepreneurship module. This type of reflection is often referred to as "reflection-in-action" (Schön, 1987). Students who lack of this reflection-in-action are likely to make mistake of repeating the same dysfunctional behavior/attitude/decision in their future career/entrepreneurial endeavor, therefore impede their advancement in their respective fields. Students who possess this appreciation of reflection demonstrate it through reflective writing. Reflective writing is a metacognitive, "thinking about your thinking" process (Martinez, 2006). As a metacognitive process, the student is able to appreciate the deeper, underlying issues (Martinez, 2006), rather than accepting a superficial interpretation of the problem, which may present in a professional/entrepreneurial context (Mair, 2011).

This research was carried out among the undergraduate students of the third and final year, majoring in entrepreneur and business administration in University Utara Malaysia (UUM). As to assess the appreciation of reflection-in-action among our students of entrepreneurship, the students were requested to hand in two reflective learning logs which contain their reflection that will be used as part of the coursework assessment for the entrepreneurship module. Yinger and Clark (1981) believed that reflection results 
JRIT\&L 10,2

128

written down are more powerful than reporting them orally. This form of writing a reflective journal has definitely being regarded as new to the students given that the norm in the coursework assessment of this module usually being quiz, mid-semester test, business plan and final exam.

This research was carried out with the two main aims as to:

(1) investigate whether students at the tertiary level who are undergoing an entrepreneurship module is able to engage in a critical reflection in the process of learning; and

(2) analyze the emerging themes on entrepreneurship from those students who are able to achieve Levels 2, 3 and 4 of Hatton and Smith's (1995) framework of critical reflection.

\section{Significance of the study}

In this study, the researcher adopts the reflective practice as a method for teaching entrepreneurship and the data collection techniques are researcher-directed textual data through reflective learning log. Given its importance, reflective skills have now being recognized as an important proficiency among the professionals and being treated as a good source for critical thinking development, enhancing self-monitoring as well as leading to one having developed good reasoning skills. Furthermore, reflective exercise has also become a vital component for most professional degree programs namely nursing, teaching as well as many business capstone courses that require final year students to recap and reflect before the end of their university's tenure (Chalk and Hardbattle, 2007). However, actually putting vague thoughts or feelings into a format that other people read is not a process that some people enjoy or find easy (Harvey and Knight, 1996) and such skills can be especially difficult to develop for Malaysia's students which traditionally have adopted instructivist learning techniques.

\section{Critical reflective learning}

It is not easy to write our thinking process in a form of reflection but it should be practiced in learning, it helps to encapsulate learning in much more meaningful manner. The use of reflection journals can assist to document thinking process which in turns helps teacher to draw conclusion on the learning progress of the students. The entire process of writing per se may have somehow encouraged students to reflect on what they have been taught in class and thus facilitate learning further. According to Cowan (1998, p. 16), a student is said to be doing reflection when "[...] she notes that there is something different about the case that she is considering, in comparison with the examples she has encountered in class; and when she also identifies what the difference is, and what she should do about it."

Dewey (1933) suggested that reflective allow one to be engaging in deep thinking in order to get an in-depth meaning of something, converting uncertainty into understanding which leads to action. This is in accordance to what Moon (1999) in which reflection entails mental activity that occurs in relation to the processing of complex ideas which are commonly found in the process of learning. Thus, so as to realize the benefits of reflection, students should be required to reflect and to write a reflective log or journal so that they can easily see the importance of the learning activities that have been carried out. As a result, reflection journal will reveal the thinking since the entire process of writing is actually a display of thinking (Luidens, 1997). Furthermore, idea clarifications and modifications happen due to the need to present knowledge in different form during the reflection writing process. As such it is expected that during this process, the learner will be able to develop new understanding and view the information in a different perspective (Yinger and Clark, 1981) 


\section{Methodology}

The research methodology used in this study was classroom-based educational action research (Angelo, 1991; Elliott, 1991). Part of effective teaching is the ability to reflect on what is happening in the classroom, and to identify any differences in what was planned and what actually occurred. By conducting "systematic, intentional inquiry" within his/her own classroom, the instructor builds a better understanding of his/her own practice (Cochran-Smith and Lytle, 1993, p. 7).

At the beginning of the academic session of 2015/2016, all students taking the BPME 3073 Entrepreneurship module in UUM had been introduced to the concept of reflection writing through the reflective learning log (Moon, 1999) that will be assessed as part of their coursework. The idea of including the reflective learning log as part of the coursework mark contribution is to entice students to participate in the exercise given that naturally students tend to behave strategically when come to their class participations. Such behavior commonly leads to the occurrence of a phenomenon known as "Strategic Students" (Kneale, 1997). In this phenomenon, students would normally resist to participate in learning beyond formal assessment requirements; point to the necessity to link assessment and learning together. Moreover, excluding the reflective learning log from formal assessment can send a negative signal to the students about the significance of reflection within the module. Nevertheless, on the hindsight, it is important to note that it can be quite impossible to know as to how the effect would take place on the comments of the students given the allocation of marks associating to the learning log.

In this qualitative research, data were collected using the reflective learning log from 140 students of three classes in which these students were requested to carry out written reflections which are assessed for final grades (contributing a maximum of 10 percent of the total coursework marks). However, students have also been informed that they will only be rewarded a maximum of 5 percent should they write their reflection in a very descriptive or reporting manner. As such, the researcher considered those students who were able to obtain a score of more than 5 percent for the reflective log exercise would be considered as those who were able to achieve the learning outcome of the formative assessment (see Table AII). Hence, in this study, students were required to keep a record of the lessons that they have learned for duration of ten weeks and then write a reflection on the particular issues of the entrepreneurship taught in each lesson based on the syllabus. At the end of the study, four students failed to hand in the learning log resulted in only 136 learning logs were used for further analysis.

Ethical guidelines were strictly adhered to which included getting their consent and keeping their identity hidden so that they could express themselves freely (Marshall and Rossman, 1999). Finally, to protect the students' privacy, we use pseudonyms in the place of real names to report our findings.

\section{Critical reflection framework}

Given that the learning log is a graded assessment, the benefits of doing reflection in the academia and at work, as well as the various types of reflective writing techniques had been informed to the students. For the purpose of grading, the author adopts the reflection framework as suggested by Hatton and Smith (1995) for the purpose of grading and subjectivity reduction. The framework contained four levels of reflections (Hatton and Smith, 1995) (which was made know to the students) as depicted below:

(1) Descriptive writing (contains no evidence of reflection) - Level 1.

(2) Descriptive reflection (a description of events with reflection from one perspective) Level 2.

Entrepreneurship students 
JRIT\&L

10,2

130

(3) Dialogic reflection (some "stepping back" from events and recognition of alternative viewpoints) - Level 3.

(4) Critical reflection (awareness that the same actions and events are viewed in a different way by different individuals) - Level 4.

In executing the study, the researcher gave an assurance to the students that their grades will not be penalized when they provide constructive criticism on the entrepreneurship module or on the taught concepts or even on the style of the lecture. In the same manner the students were also being reminded that their grades will not be affected positively as it contain purely praises for the said module. The students were told that evaluation will solely be based on the quality of reflection shown based on the Hatton and Smith's (1995) framework.

A very basic scaffolding framework was provided for the reflective task which gave students three prompts which they could structure their reflection around; what have you learnt from the module so far? What are the topics in this module that give you many insights on becoming an entrepreneur? How will you be able to use the knowledge from this module in your professional career? The prompts were aimed at leading the students away from writing a descriptive reflection ordered by the topics taught on the module. Only 12 students utilized the framework, the majority completed a free style reflection. The fact that so few students used the framework may mean they found it difficult to use because it was designed to discourage descriptive answers and promote reflective thinking. The students may also have felt that they did not need guidance to help them structure their reflection or even that the mark given (10 percent) for the reflection did not warrant spending too much time writing it.

\section{Analyses and discussions}

Based on the mark sheets for reflective learning log (see Table AII), Table I tabulates the frequency of score percentage for graded reflective learning log.

All of the reflections in the findings section were taken from the students that have achieved the score of 6 percentage points to 9 percentage points from the total score of 10 percentage points based on Table AII. A total 75 (approximately 55 percent) of the reflective logs were identified as Level 1 (from 1 to 5 percent) in which reflections were simply written in a descriptive manner in the absence of reflections on the weekly lessons. Consequently these learning logs were removed from analysis; resulted in a balance of 61 learning logs being utilized for further analysis. Given that the numbers of learning logs (75 logs altogether) that have been discarded for further analysis were large (approximately 55 percent), it may provide a significant indicator that the task of doing reflection can be challenging due to the lack of ability in reflective thinking or it could also be an indication that the students were simply not interested in pursuing the assessment completely.

Notwithstanding the importance of reflective exercise to undergraduate students, the author found out that most of the 140 students had taken subject ranging from 18 to 30 subjects (Table AI), yet this is the first time they were required in this entrepreneurship module to write reflective learning log in their formative assessment. Many of the samples did not achieve the learning outcome of the reflective learning log objectives (see Table AII).

Table I.

$$
\text { Score percentage }
$$

Frequency

Frequency of score 
All of the 140 students in this module had taken more than 18 subjects prior to this module. Some of the students, at the time of this study being carried out, had even registered/taken 30 subjects prior to this entrepreneurship module (see Table AI) and yet it was the first time they were being asked to write reflective learning log in their formative assessment. Absence of such experience had led to the students not being able to do reflection effectively which in turns having many of them merely able to engage in Level 1 of writing that is descriptive writing while others only able to reach the Level 2 of writing known as the descriptive reflection which normally look at events from a single point of view.

A thematic approach was utilized to present the reflections of the 61 reflective learning $\operatorname{logs}$ (in anonymity) and all data were recorded in a verbatim format. In analyzing the data, we used open coding (based on constant comparative methods) (Strauss and Corbin, 1998) to identify themes to represent repeated ideas that emerged across the reflections about their experiences in entrepreneurship module. We assigned labels to the reflective learning logs, as a means to identify patterns in the students' reflection and discussion. We engaged in peer examination to ensure that our analysis was reliable and that our own biases and predispositions would not affect our interpretation of the data (Gray, 2004).

\section{Discussions}

The students' reflections on their entrepreneurship's experience could be grouped into four different reflection organizing themes comprised of:

(1) the nature of entrepreneurship module;

(2) entrepreneurial characteristics;

(3) opportunity recognition; and

(4) creativity and innovation.

Each of these themes is described by student reflections that are found to be fulfilling the criteria of reflective learning log (all of these reflections were taken from the students that have achieved the score of 6 percent points to 9 percent points from the total score of 10 percent points). Last but not least, the final sub-section of the results highlights the descriptive nature of reflective learning log (of those which do not fulfill the reflective log criteria as according to the Level 1 of the Hatton and Smith's (1995) framework with the score percentage point was from 1 to 5 percent). This research analyses the students' reflections to ascertain their views on the topics that the module covered and their reflective ability. A reflective learning log normally contains a record of one's experiences, thoughts, feelings and reflections (Miller et al., 1994).

\section{Entrepreneurship module}

This theme looks at whether students were able to do reflection which is related to the entrepreneurship module as itself. This study found that there were 45 samples contained reflections that were related specifically to the nature of entrepreneurship from a total of 61 reflection logs. In addition, there were 30 students who found the entrepreneurship module interesting even though some of the students (six students) felt the module is not benefitting them at all given the opinions that the module contains topics that do not relate to one being an entrepreneur. Some people say - entrepreneurship cannot be taught in the classroom setting. Below were the excerpts from our students whose names had been disguised:

Wan Ting: In my own opinion, entrepreneurship is a subject that not needs study in university. It is because, entrepreneurship is the person who dislike study and lazy to work and my friend tell me that, nowadays, if u got degree, your salary also no enough to cover your life. So, she decide to stop hers study and go to find hers own goal. That time, I can't understand. Why she wants to stop hers 


\section{JRIT\&L} 10,2 study? If she wants to venture, she also can start after she graduate. So, I dislike this subject and it also no useful for me (sic).

Wan Ting was questioning the legitimacy of this module as she found this module was not useful for her. From her anecdotal example presented above, she opined that to be an entrepreneur, she does not need to study entrepreneurship as a subject because many successful entrepreneurs never set foot in the ivory tower, they just do it (she quote the budding entrepreneur dislike study). She even goes to the great length to argue that a degree was not sufficient to guarantee a successful life thereafter:

Samantha: I felt this subject "Entrepreneurship" was an unnecessary subject for me. From my last experienced, I felt bored and I'm taking this subject because I'm just wants to finish up my syllabus! For my perspectives, I think we totally don't have to take this course. For me, to become a successful entrepreneur is not just study all these theories only. Even though we have memories and study all the theories, but it is still not guarantee us to become a successful entrepreneur. Instead for those entrepreneurs, even though they are not taking this subject but they will also become a successful entrepreneur. I don't think so this subject can cultivate the entrepreneur, maybe can but I think is just a few only! I hope also can become a successful entrepreneur in one day! (sic).

As like Wan Ting, Samantha, also poured her heart out on this subject in the negative way (unnecessary subject for me). Samantha wants to be a successful entrepreneur but she did not think study the module per se with all the entrepreneurship's concepts and theories will transform her to become one (it is still not guarantee us to become a successful entrepreneur). Like Wan Ting, Samantha also questioned the legitimacy of this module as they felt bored, wasting their time and to the very core, they just to complete their credit hours of this module to obtain a degree.

But what expressed above by Wan Ting and Samantha did not reflect the current trend in the world of business and academic. In recent years, we have seen an extraordinary proliferation of entrepreneurship and small business courses and programs in colleges and universities worldwide (Solomon, 2006). From its origins until today, entrepreneurship research and teaching has met many important milestones. It appears that such rocketing interest in entrepreneurship has shaped not only scholarly writing, but also initiated a "revolution" in entrepreneurship education at academic institutions. This "revolution" has also sparked an interesting scholarly discourse between Kuratko $(2004,2005)$ and Katz (2006, 2008) about the maturity and legitimacy of entrepreneurship as not only a field of study but also a field relevant to higher education.

In other words, the adoption of programs (i.e. entrepreneurship) makes the higher education institutions like UUM relevant and it signals that UUM graduates have the preparation they need to succeed in a competitive environment. This goes as far as hiring employees based on the legitimacy they provide to the institution (UUM) rather than their (graduates) actual capabilities. This should augur well for UUM graduates like Samantha and Wan Ting as it was compulsory for all bachelor of business undergraduates to take this module.

As with entrepreneurship's theories as highlighted by Samantha, Fiet (2001) specifically addressed this issue when he observed the large number of adjuncts that teach entrepreneurship:

Students must learn theory in order to understand the future consequences of their entrepreneurial decisions. Thus, it seems improbable that adjuncts can effectively teach the course. Teaching theory is rarely the strength of adjuncts (Fiet, 2001, p. 9).

Adi: My first impression on this class is that it is actually quite interesting as I am uninterested on this class at first as I thought that this class will be a very hard one and involve a lot of reading. Indeed it does involved a lot of reading but it is interesting that I sometimes imagine myself in the situation or topic that I read. For example, franchising is a very famous topic related to entrepreneurship. So, it makes me imagine that someday I will have my own franchise and how 
I will manage it. As a Malay myself, of course I would really like to be just like these successful Entrepreneurship entrepreneurs below and I would really want to see myself to be as good as them in the future (sic).

Kee Keat: Based on the knowledge that I had learned in the class, I have a clearer understanding about what is entrepreneurship and it change many of my misconception about entrepreneurship. It really inspires me. However, becoming an entrepreneur is not an easy task because they have to face many problems and make the best choice of every decision. It needs a good planning before we start our business (sic).

Despite an initial lukewarm interest in the module, a change in Adi's behavior and the comments from Kee Keat can be seen among the students when they started to view how the module content can be useful for them. Most of the reflection of the students has similar comments as the one depicted by Adi in which, the expression of relishing certain topics of the entrepreneurship module is prevalent and how the module as a whole had changed their worldview of entrepreneurship forever. This module also stimulates Adi's imagination as he envisions himself as a successful franchise entrepreneur in the future. He went on to search list of successful Malay entrepreneurs so that Adi can emulate and be good as them. As for Kee Keat, he managed to correct its misinterpretations on the concepts of entrepreneur and aspire to become one. He also has high awareness that to start a business is no easy feat can be done with good planning (it needs a good planning before we start our business).

\section{Entrepreneurial characteristics}

All 61 logs contained reflections that related to the entrepreneurial characteristics. In total, 35 students made specific reflections that learning entrepreneurial characteristics had demonstrated the importance of "taking calculated risk, ideation, control of our own future," something they had not done previously or that the "module has made me rethink my personal beliefs and has made me consider to become entrepreneur." Many students made specific reflections about their intention to use whatever they had learnt on the module to help them venture into their small businesses and achieve their "dream." In a nutshell, this topic uncovers what make a successful entrepreneur like Tony Fernandez and Richard Branson "thick":

Hafiz: From the lesson of this week, I could understand that entrepreneur is a person who is taking a calculated risk. This is meant that entrepreneur is not a gambler who is just trying luck without any effort. To become an entrepreneur, firstly we have to identify the opportunity that we see and use the opportunity wisely to enhance our life and also the community's life. As example, Tony Fernandez who is the owner of Air Asia starts his business by making a loan to government. His idea is brilliant (sic).

The above account by Hafiz highlighted many intrinsic value of an entrepreneur, namely, calculated risk, opportunity identification, community's life enhancement and ideation. There is clear evidence of dialogic reflection by citing Tony Fernandez from Air Asia. Hafiz is making an association between all the good values espoused by an entrepreneur and connects it with his icon, Air Asia's Boss. Hafiz further draws the inspiration on how young people like him can learn so much from Tony as a successful entrepreneur:

Saidatul: I found out that even women also have a big potential to become a successful entrepreneur. The entrepreneur not only belongs to man. This video proves that women also have the entrepreneur characteristics that the men had. The women also have the strong passion and interest to become an entrepreneur and this passion doesn't less than men had. In my opinion, everyone also can become a successful entrepreneur no matter the gender, age, and nation. It is only depends on the person themselves that they really want to be (sic).

Saidatul reflects emotionally for the above account. As a woman, Saidatul strongly opined that successful entrepreneur does not belong to man only; woman as shown in the video during the class can also become successful. In her frame of mind, woman equal with man in the endeavor of entrepreneurship. Clearly, in this account, self-questioning is evident (an "internal dialogue" 
JRIT\&L 10,2

is set up at times) in Saidatul and she is deliberating between different views of her own mindset on woman entrepreneur (before and after watching the video on Ugandan woman entrepreneurs in making straw bag). This account shows quite deep reflection, and it does incorporate a recognition that the frame of reference with which an event is viewed can change according to the emotional state in which it is written, the acquisition of new information (through the video), the review of ideas and the effect of time passing:

Kamariah: But the most interesting thing in this first chapter is that it makes me think more whether I should be an entrepreneur or not, and if I want to be an entrepreneur why? As I think all over again, I think that being an entrepreneur might be a good thing for me because I really want to have a full control of my own life, and give something to my family especially my parents, and lives like how I have dream before. But then when think about the challenges to be an entrepreneur nowadays, it kind of breaking me apart as I picture myself in a very difficult situation if I become an entrepreneur. Just thinking about the competition that I will faced makes me wondering how tough the life it is for those successful entrepreneur when they first started (sic).

Like Saidatul, Kamariah is self-questioning herself (whether I should be an entrepreneur or not?). Kamariah is deliberating between different views of her own behavior (different views of her own and others). She delves into the question "Why I want to become entrepreneur"? She not only starts to envision the benefits of becoming one successful entrepreneur, but also worry about the huge challenges that are going to be encountering before becoming one. Kamariah says "But then when think about the challenges to be an entrepreneur nowadays, it kind of breaking me apart as I picture myself in a very difficult situation." This shows Kamariah is learning new skills in contemplating and decision making. In addition, it unveils the feelings of insecurity when she visualizes the difficult road ahead of a budding entrepreneur:

Tina: There are a few characteristics of an entrepreneur. Dare to take risk, hardworking, creative and innovative, open-minded, energetic, self-confident, and optimistic are some of the characteristics of the entrepreneur. Some of the people believe that entrepreneurs are born not create. However, it is not true. Most of the entrepreneurs are force to be an entrepreneur because of their condition. Sometimes, when people migrate to the other place, they will start a new business too because they have nothing at the new place. Beside, entrepreneur nowadays are born through knowledge. There are myths that say that "entrepreneur is those who do not do well in their academic." However, I do not agree with it (sic).

Tina critically analyzed and opined that: "Some people believe that entrepreneurs are born not create. However, it is not true." She recognizes how prior experience, thoughts (own and other's) interact with the production of her own behavior. She gave her own opinion and explains critically that: "Most of the entrepreneurs are forced to be an entrepreneur because of their condition." She goes on to explain all the rationale of why entrepreneur is not born, but due to their predicaments. She also cited that immigrants tend to become entrepreneur in the host country because their lack of origin endowment. Again, self-questioning is evident in her reflection; deliberating between different views of her own behavior (different views of her own and others). She further says that: "entrepreneur nowadays are born through knowledge" and use this statement to debunk the myths that says: "entrepreneur is those who do not do well in their academic."

Tina succinctly supported her argument with: "entrepreneurship has become a core subject for every university's students," such as in the Malaysian context, therefore, all Malaysian entrepreneurs are well educated in the future. This is a logical argument. There is clear evidence of dialogic reflection in the final writing of Tina. Ironically, Tina reflection on the last thought of well-educated entrepreneur stand in total contrast with the reflection of Wan Ting, which says: "Entrepreneur is the person who dislikes study."

\section{Opportunity recognition}

As with entrepreneurial characteristics, all 61 logs contained reflections that related to the theme of opportunity recognition. Opportunity recognition is the essence of 
entrepreneurship as entrepreneur is all about spotting and acting on opportunity. According Entrepreneurship to the definition that research works consider opportunity to be laying at the heart of the entrepreneurial process, an entrepreneur is an individual who is able to identify, evaluate students and exploit opportunities (Shane, 2003; Venkataraman, 1997):

\begin{abstract}
Akhmal: How we define opportunities? What if, when opportunities come, and we don't know anything about it? After the class I try to search on the internet about the definition of opportunity. Then only I realize that, there's no any clear definition about. Let's say in one situation, there's very less people selling fried banana at the area, then a person start a fried banana business without realizing these factors. Does it mean that the person didn't recognize the chance and grab it? In my understanding, I don't think the person grab the opportunity although he done a great job. To me, opportunity recognition more towards the person keep thinking about what kind of food has not been selling at his area, then he figure out that it's fried banana! (sic).
\end{abstract}

Reflection by Akhmal depicts the student engaging in asking self-critical question about what is "opportunity." That made him/her thinks very hard on this magic word and then synchronizes the meaning of "opportunity" to his/her own cognitive map.

Self-questioning is evident: "What if, when opportunities come, and we don't know anything about it?" This critical question posed by Akhmal demonstrated that there are sense of "mulling about," discourse with self and an exploration of the role of self in entrepreneurship module. Akhmal try curiously to find the meaning of "opportunity." Even though Akhmal cannot find one to his satisfaction, but he try to make sense of the term with a good example. The example given showed Akhmal try hard to find closure on the term "opportunity":

Qistina: When talking about opportunity, here is a company that using opportunity wisely - Khan Academy. When I visit his website www.khanacademy.com there are thousands of education resources which provide variety of subject such Mathematic, History, Healthcare, Medicine, and a lot more. When I heard that Khan Academy is a nonprofit organization, I truly curious about how he makes his money and get the financial resources. Then after make a research actually his revenue come from donation from Bill Gates and Google and also from advertising. Finally, I found out that Khan Academy becoming a powerful brand name in education it is because "they delivered value to people" (sic).

Qistina reflection signifies descriptive reflective. There is basically description of events on Khan Academy, but shows some evidence of deeper consideration in relatively descriptive language (e.g. I truly curious about how Khan Academy makes his money and gets the financial resources). Qistina linked her writing to the global organization like Khan Academy and she did a lot of research in order to complete her reflection. This is out of curiosity on Khan Academy. This is one of the benefits of reflective learning log as students reflect and engage actively in certain topics/themes, they tend to search and research extensively in order to close their "knowledge gap":

Nurahimah: I once worked at a supermarket that sells goods worth RM2. I found many buyers purchase goods in our store because the price is cheaper than other stores. In uncertain economic conditions, high prices can temp customers to switch to a store that can offer low prices for them. This shows that the entrepreneur can use creative pricing strategy in uncertain economic condition as an opportunity to sell their product.

In the above account, Nurahimah try to connect her working experience in supermarket and the entrepreneurial concepts of creative pricing, opportunity and economic conditions. Nurahimah use her keen sense of observation to deduce the concepts of "opportunity" by making a connection between low price strategy and uncertain economic situation. Her reflection signifies opportunity never fall from the thin air but rather through skillful orchestration between strategy and environment:

Kee Keat: Opportunity is very important for an entrepreneur because opportunity is rather than just idea. If an entrepreneur has a good idea, but he or she do not has the chance to present or show to the other which mean that his or her idea will not be known by the public and hard to success. 
JRIT\&L 10,2
They always need to observe and understand the trend of the business. In addition, they will not miss the opportunity which will change the future of the business. Beside, entrepreneur must be sensitive to the surrounding. A little change of the environment may lead to a huge change of the business especially the technology. Therefore, every entrepreneur must put effort in finding the opportunity and sensitive to the surrounding to ensure that their business can be success.

Kee Keat reflective writing is a metacognitive, "thinking about your thinking" process (Martinez, 2006) through "Opportunity is very important for an entrepreneur because opportunity is rather than just idea. If an entrepreneur has a good idea, but he or she does not have the chance to present or show to the other which mean that his or her idea will not be known by the public and hard to success" and "A little change of the environment may lead to a huge change of the business especially the technology."

The above account requires Kee Keat to use analytical skills (i.e. higher order thinking skills), to differentiate between idea and opportunity rather than merely create a narrative. As a metacognitive process, Kee Keat is able to appreciate the deeper, underlying issues of entrepreneurship (Martinez, 2006), rather than accepting a superficial interpretation of the problem, which may present in an entrepreneurial context such as technological advancement (Mair, 2011).

\section{Creativity and innovation}

Only 45 reflections contained comments that related to the topic creativity and innovation. Many reflections cite that there are vast differences between creativity and innovation. Shane (2003) emphasized an entrepreneur's creative role in innovation, with the observation that many founding teams use various forms of brainstorming to increase the number of new ideas, and thus enhance creativity as an important foundation for innovation. For many business students and the budding entrepreneur, innovation becomes the focal point of the reflections:

Wen Hui: Entrepreneurs need to create new ideas in business to produce new products not yet available in the market and that cannot be imitated by competitors. For example, Cirque de Soleil, which uses "Blue Ocean Strategy", in a business where no entrepreneurs who are able to provide competition in the business. Cirque de Soleil has been doing business unique circus where it has employees who have high expertise and exceptional in doing interesting acrobatic actions. This business received overwhelming response from customers because it is different from the normal circus (sic).

Wen Hui quote world class circus like Cirque du Soleil, which uses "Blue Ocean Strategy" come to the fore of his/her reflection. She was able to connect creativity and innovation with Cirque du Soleil. Blue Ocean Strategy requires entrepreneur to create new ideas to produce new products not yet available in the market and cannot be imitated by the competitors. The uses of this unique example demonstrated the depth of propositional knowledge and the ability of Wen Hui to connect innovation and business bottom-line:

Zuliana: Today lecturer let us watch a video about woman entrepreneurs in Uganda. From this video I can see it is a very poor country. Yet, people did not give up their life; they are doing hard work for success, especially for woman entrepreneurs. A woman entrepreneur collects used straw from rubbish site, recycle the used straw and transform product like into lady handbag, shoes, and woman accessories. From here I see the woman entrepreneurs are very creative. When the machine used to flatten the straw breakdown, she even used her own teeth and knife to flatten the straw (sic).

Zuliana is touched by the heart-wrenching video showcased true-grit creative woman entrepreneurs in a poverty stricken country called Uganda. Through this video, Zuliana narrates what she observed from the hard lives of woman entrepreneur in Uganda. The description is succinct - just sufficient to raise the issues. Extraneous information is not added. It is not a story. The focus is on the attempt to reflect on the event and to learn from it. There is more of a sense of Zuliana standing back from the event in the video; in order to reflect better on her actions and in order to be more effectively critical. 


\section{Descriptive writing (non-existence of reflection)}

In this SoTL, there were 75 samples of reflective learning logs that scored 5 percent and below 5 percent point (see Table AII). All of them achieved Level 1 (non-existence of reflection) in the reflective framework proposed by Hatton and Smith (1995). Descriptive writing is a description of events or literature reports. There is no discussion beyond description. The writing is considered not to show evidence of reflection. The followings are some of the accounts:

Asmida: Franchise is a semi-independent business that individual pays the fees and royalty for the trademark that will be used to sell the product and their service. This business is easier compare to the individual that want to open their own business. For example like Mc Donald which has franchise for all over the whole that many franchisees pay the fees to run their business (sic).

This account written by Asmida is descriptive and it contains little reflection. The account describes what is franchise, its characteristics and some of the benefits - but all in the context of an account of the event. Generally one point is made at a time and ideas are not linked. It was wordy, tended to be meaningless and lacked sophisticated vocabulary. Overall, the writing was particularly colloquial in style:

Tina: An entrepreneur is someone who organizes, manages, and assumes the risks of a business or enterprise. An entrepreneur is an agent of change. Also, an entrepreneur who is makes a profit. The profit-and-loss system of capitalism helps to quickly sort through the many new resource combinations entrepreneurs discover (sic).

The above definition written by Tina was well versed but the entrepreneurial concepts are taken on without questioning them or considering them in depth. It is very descriptive. It could be a reasonably written account of an event that could serve as a basis on which reflection might start on an entrepreneur's risk taking behavior and efficient resource allocation through the profit-and-loss system, though it hardly signals any material for reflection - other than the last few words stated "positive side of business failure":

Hafiz: During the week, I study the new chapter about related to business networking. In my opinion, in this kind of business network should be established and it is important to keep the business continue business gaining strength and develop. There are several types of networking. In the class as well, lecturer explains the strategy to build a network that is, build, consolidation and retention. My comment about this thing is my very interest to know more about this topic (sic).

The account is written only from one point of view - that of Hafiz. Its narration is both surface and superficial without any substance content for critical reflection in the context of business networking. The idea is not relevant or focused, such as "My comment about this thing is my very interest to know more about this topic." There were also significant problems with grammar, characterized by multiple errors in the original transcript of the Hafiz. Apparently, there is a lack of checking in the process of preparing this reflective learning log:

Ahmad: Lecturer continue new chapter that getting funding or financing. In this chapter lecturer explains why most new ventures need financing or funding. In addition there is also help to find alternative financial sources such as personal fund, equity capital, debt financing and creative sources. Lecturers are also explains about bootstrapping, other word is thrifty and there are 9 example of bootstrapping methods (sic).

Instead of using first party address, Ahmad tends to use third party address such as lecturer in writing his reflection. Critical reflection very much focused on the individual discourse with self and an exploration of the role of self in events and actions. The above narration is very much descriptive in nature and hardly contains any significant materials for reflection. The writing reflects a mere regurgitation of learning materials from the textbooks and the lecturer's power point slides. There was a lack of sophistication in the writing.

Entrepreneurship students 
JRIT\&L 10,2
The reflection by the above four sampled students in this study indicated the reflective learning log were descriptive in nature. The writings from the reflection learning log were a mere regurgitation from the power point slides and textbooks given in lectures throughout the 14-week class. They were written in reporting style, all in the context of an account of the event and more like registering everything happen in those particular week. The reflective learning log failed to address things like thoughts, feelings, how well (or bad) it went, what the students had learnt, and what he/she will do differently next time (Miller et al., 1994). Based on the frequency of score for graded reflective learning log, 75 students merely self-reported the contents of the lectures throughout the semester that have no reflection at all (some of their reflection were highlighted in the reflections of students 16-20). Another 35 students produce the works that contain descriptive reflection from one perspective. Only 26 students were able to reflect critically at Level 4 (Hatton and Smith, 1995) in certain themes in entrepreneurship module.

\section{Implications and limitations}

This study highlighted that reflective writing was an unfamiliar genre to many business students and needed to be explicitly taught in the respective subject. The results of this study have strongly suggested an urgent need for the development of reflective writing skills among the students during their higher education studies so as to assist in the professional and entrepreneurial behavior development as they entered the job market. In addition, there is a necessity to equip the undergraduate with basic building blocks needed to mold them as reflective practitioners. The reflective framework provided by Hatton and Smith (1995) proved to be useful in categorizing the written reflections and making the grading of the reflective learning log as less subjective. The weightage given to this graded assessment was 10 percent and it is considered substantial in grade. While the result of the study may not provide strong evidence on the ability of the students in reflective writing, it will be strange should inability exist as the outcome of attitudinal problem of willingly forgo a set of marks by not writing reflectively in which may warrant further investigation.

Based on the result of the 61 students who had demonstrated an ability in reflective writing, it is suggested that perhaps the university should consider offering coursework that contains a component of reflective writing as part of the assessment. As such, if this is implemented, students of such ability like the one in this sample group would have been benefitted from such assessment which look at reflective ability (Greene, 2014) and which they were allowed to form a broader perspective in relation to the module undertaken. This in turns will foster the growth of reflective ability which is recognized as a learned behavior (Gustafson and Bennett, 1999). In addition, for the future exercise of this reflective learning $\log$, the researcher opined that we should encourage our students to engage with another student (e.g. close friend) in a way that encourages talking with, questioning, or confronting, helped the reflective process by placing the learner in a safe environment in which self-revelation can take place. In addition, students were able to distance themselves from their actions, ideas and beliefs, by holding them up for scrutiny in the company of a peer with whom they are willing to take such risks (Hatton and Smith, 1995).

The researcher found that more than half of the students were only able to reach Level 1 of reflection as suggested by Hatton and Smith (1995), the idea of giving additional specific guidelines will lead the students to certain stereotypes of writing reflective learning log (Stamper, 1996) and that may prove counterproductive. As such Holland (2013) suggested that it is only necessary for reflective writing skills being developed with the reflective thinking skills so as to assist in the ability of the students to write a good reflection.

Results which show the mark sheets for reflective learning log (see Table AII) indicate that most of the students need to be given greater opportunities for reflective writing skills development throughout their tertiary learning. This study suggested the importance of 
having a blend of reflective writing exercise in most of the subjects at the undergraduate Entrepreneurship degree so as to facilitate not only dispersing knowledge on their module professional aspects but also create of pools of reflective practitioners in the future.

As for the limitation of the study, it is important to not to underestimate the challenges of introducing a grade assessment that most of them are not familiar with in their university academic journey. Students need guidance, assurance and confidence writing something that require personal opinion, own thinking, sensitive and personal nature of narration. For most students as found out in this study, self-confessional writing is hard to come by (they dare not attempt it in the first place), only a handful appreciating the writing start with "I," "me" as first person. More research in this study should be conducted across the university to gauge the response from the students to see if the result of this study is only applicable to this group of students or to this discipline of studies. The researchers would also like to recommend for future studies which take the form of a longitudinal study of similar kind to examine the problems and challenges with regards to promoting learning reflection at the undergraduate level.

\section{Conclusions}

By maintaining a learning log for the past 14 weeks in this entrepreneurship module, students can record and comment their every week entrepreneurship lessons in a profound manner. They can self-track their perspectives in their first class in this module and monitor their evolved entrepreneurship knowledge and perspectives as the lecture progress until the end of the semester. In the process, they immerse in self-discovery in the world of entrepreneurship and self-tracking personal growth and cognitive development. Reflective learning log enables students to clearly identify their own thinking in entrepreneurship, the risks involved, the myths of becoming an entrepreneur, opportunity and execution intelligence - a method that promotes deep learning as depicted in the student's comments in the findings section in this study. Research has identified that reflection can help people to change. Although most of the students registering for this module are young undergraduate, and have limited experience to draw from to reflect upon certain issues (this is the findings from this study). But despite these barriers, reflective learning log makes entrepreneurship learning congruent with the suggestion to teach entrepreneurship as a method rather than as a process. Reflective learning log provides students with a profound insight into their own world of academic and; hopefully in future, their professional growth as reflection become a habit for my student.

\section{References}

Angelo, T.A. (1991), "Introduction and overview: from classroom assessment to classroom research", in Angelo, T.A. and Cross, K.P. (Eds), Classroom Research: Early Lessons from Success, Jossey-Bass, San Francisco, CA, pp. 7-15.

Chalk, P. and Hardbattle, D. (2007), "Does reflective writing in PDP improve science and engineering students learning?", Investigations in University Teaching and Learning, Vol. 4 No. 2, pp. 33-41.

Cochran-Smith, M. and Lytle, S.L. (1993), Inside Outside: Teacher Research and Knowledge, Teachers College Press, New York, NY.

Cowan, J. (1998), On Becoming an Innovative University Teacher: Reflection in Action, The Society for Research into Higher Education and Open University Press, Buckingham.

Dewey, J. (1933), How We Think?, D.C. Heath and CO, Boston, MA.

Elliott, J. (1991), Action Research for Educational Change, Open University Press, Philadelphia, PA.

Fiet, J.O. (2001), "The pedagogical side of entrepreneurship theory", Journal of Business Venturing, Vol. 4 No. 2, pp. 101-117.

Gray, D.E. (2004), Doing Research in the Real World, Sage, Thousand Oaks, CA.

Greene, P.G. (2014), Four Approaches to Teaching Entrepreneurship as a Method, Babson College, MA. 
JRIT\&L 10,2
Gustafson, K. and Bennett, W. (1999), "Issues and difficulties in promoting learner reflection: results from a three-year study", available at: http://it.coe.uga.edu/ kgustafs/document/promoting.html

Harvey, L. and Knight, P. (1996), Transforming Higher Education, SRHE and Open University Press, Buckingham.

Hatton, N. and Smith, D. (1995), "Reflection in teacher education - toward definition and Implementation", Teaching and Teacher Education, Vol. 11 No. 1, pp. 33-49.

Holland, L. (2013), "Student reflections on the value of a professionalism module", Journal of Information, Communication and Ethics in Society, Vol. 11 No. 1, pp. 19-30.

Katz, J.A. (2006), “And another thing”, white paper, USASBE National Conference, Northridge.

Katz, J.A. (2008), "Fully mature but not fully legitimate: a different perspective on the state of entrepreneurship education", Journal of Small Business Management, Vol. 46 No. 4, pp. 550-566.

Kneale, P. (1997), "The rise of the 'strategic student': how can we adapt to cope? In facing up to radical changes in universities and colleges", in Armstrong, S., Thompson, G. and Brown, S. (Eds), Kogan Page/SEDA, London, pp. 119-130.

Kuratko, D.F. (2004), "Entrepreneurship education: emerging trends and challenges for the 21st century", Keynote Address at the US Association of Small Business and Entrepreneurship, Northridge, available at: www.usasbe.org/pdf/CWP-2003-kuratko.pdf

Kuratko, D.F. (2005), "The emergence of entrepreneurship education: development, trends, and challenges", Entrepreneurship Theory \& Practice, Vol. 29 No. 5, pp. 577-597.

Luidens, P.M. (1997), "Paper thinking: the process of writing", in Costa, A.L. and Liebmann, R.M. (Eds), Envisioning Process an Content: Towards a Renaissance Curriculum, Paper No. 11, Corwin Press, Thousand Oaks, CA.

Mair, C. (2011), "Using technology for enhancing reflective writing, metacognition and learning", Journal of Further \& Higher Education, Vol. 36 No. 2, pp. 147-167.

Marshall, C. and Rossman, G.B. (1999), Designing Qualitative Research, 3rd ed., Sage, Thousand Oaks, CA.

Martinez, M.E. (2006), “What is metacognition?”, Phi Delta Kappan, Vol. 87 No. 9, pp. 696-699.

Miller, C., Tomlinson, A. and Jones, M. (1994), Researching Professional Education, University of Sussex, Brighton.

Moon, J. (1999), Reflection in Learning and Professional Development: Theory and Practice, Kogan Page, London.

Schön, D. (1987), Educating the Reflective Practitioner, Jossey-Bass, London.

Shane, S.A. (2003), A General Theory of Entrepreneurship: The Individual-Opportunity Nexus, Edward Elgar Publishing, Cheltenham.

Solomon, G.T. (2006), "Are we teaching small business management to entrepreneurs and entrepreneurship to small business managers?", white paper, USASBE National Conference, Northridge.

Stamper, C. (1996), "Fostering reflective thinking through computer mediated journaling", unpublished doctoral dissertation, Arizona State University, Tempe, AZ.

Strauss, A. and Corbin, J. (1998), Basics of Qualitative Research: Grounded Theory Procedures and Techniques, 2nd ed., Sage, Thousand Oaks, CA.

Venkataraman, S. (1997), "The distinctive domain of entrepreneurship research", Advances in Entrepreneurship, Firm Emergence and Growth, Vol. 3 No. 1, pp. 119-138.

Yinger, R.J. and Clark, C.M. (1981), "Reflective journal writing: theory and practice", Occasional Paper No. 50, Institute for Research on Teaching, Michigan State University, MI.

\section{Corresponding author}

Khar Kheng Yeoh can be contacted at: kharkheng@uum.edu.my 


\begin{tabular}{|c|c|c|c|c|c|c|c|c|}
\hline Matric no. & $\begin{array}{c}\text { Total subjects } \\
\text { taken (subject } \\
\text { with reflective } \\
\text { learning log) }\end{array}$ & Matric no. & $\begin{array}{c}\text { Total subjects } \\
\text { taken (subject } \\
\text { with reflective } \\
\text { learning log) }\end{array}$ & Matric no. & $\begin{array}{c}\text { Total subjects } \\
\text { taken (subject } \\
\text { with reflective } \\
\text { learning log) }\end{array}$ & Matric no. & $\begin{array}{c}\text { Total subjects } \\
\text { taken (subject } \\
\text { with reflective } \\
\text { learning log) }\end{array}$ & \\
\hline 219,792 & $30(1)$ & 227,437 & $17(1)$ & 225,447 & 17 (1) & 227,810 & 20 (1) & 141 \\
\hline 219,868 & 25 (2) & 227,440 & 21 (1) & 225,513 & 18 (1) & 227,976 & 19 (1) & \\
\hline 220,372 & 28 (2) & 227,576 & $21(2)$ & 225,628 & 18 (1) & 228,031 & 20 (1) & \\
\hline 220,488 & $30(2)$ & 227,584 & 21 (1) & 225,707 & 17 (1) & 228,050 & 18 (1) & \\
\hline 220,540 & 29 (1) & 227,875 & 19 (1) & 225,740 & 17 (1) & 228,068 & 18 (1) & \\
\hline 221,390 & 29 (1) & 228,011 & 19 (1) & 225,837 & 19 (1) & 228,346 & 19 (1) & \\
\hline 221,573 & 29 (2) & 228,018 & 19 (2) & 225,949 & 19 (1) & 228,348 & 19 (1) & \\
\hline 221,577 & 29 (1) & 228,064 & 17 (1) & 225,955 & 18 (1) & 228,492 & 16 (1) & \\
\hline 221,632 & 29 (1) & 228,382 & 19 (1) & 225,986 & 19 (1) & 228,504 & 17 (1) & \\
\hline 221,812 & 28 (1) & 228,405 & 19 (2) & 226,036 & 18 (1) & 229,131 & 19 (1) & \\
\hline 221,822 & 29 (1) & 228,416 & 18 (1) & 226,058 & 17 (1) & 229,135 & 18 (1) & \\
\hline 221,862 & 29 (1) & 228,563 & 14 (1) & 226,100 & 18 (1) & 216,678 & 33 (1) & \\
\hline 222,068 & 30 (1) & 228,592 & 15 (1) & 226,211 & 18 (1) & 222,146 & 30 (1) & \\
\hline 222,071 & 29 (1) & 229,128 & 19 (1) & 226,309 & 18 (1) & 223,193 & 29 (1) & \\
\hline 222,083 & 29 (1) & 230,227 & 12 (1) & 226,633 & 18 (1) & 223,206 & 31 (1) & \\
\hline 222,302 & 33 (1) & 230,276 & 12 (1) & 226,689 & 18 (1) & 223,214 & 30 (1) & \\
\hline 222,342 & 28 (1) & 219,701 & 30 (1) & 226,857 & 18 (1) & 223,244 & 29 (1) & \\
\hline 224,135 & 23 (1) & 220,781 & 30 (1) & 227,145 & 18 (1) & 223,305 & 29 (1) & \\
\hline 225,622 & 18 (1) & 220,807 & 29 (1) & 227,160 & 18 (1) & 225,727 & 29 (1) & \\
\hline 225,976 & 18 (1) & 221,298 & 28 (1) & 227,167 & 17 (1) & 225,776 & 18 (1) & \\
\hline 226,101 & 21 (1) & 221,318 & 28 (1) & 227,272 & 17 (1) & 225,781 & 18 (1) & \\
\hline 226,168 & 19 (1) & 221,447 & 30 (1) & 227,315 & 19 (1) & 226,106 & 18 (1) & \\
\hline 226,245 & 18 (1) & 222,041 & 29 (1) & 227,492 & 19 (1) & 226,176 & 18 (1) & \\
\hline 226,281 & 18 (1) & 222,093 & 29 (1) & 227,599 & 17 (1) & 226,184 & 18 (1) & \\
\hline 226,296 & 18 (1) & 223,304 & 18 (1) & 227,606 & 18 (1) & 226,297 & 18 (1) & \\
\hline 226,566 & 18 (1) & 225,280 & 18 (1) & 227,649 & 18 (1) & 226,321 & 18 (1) & \\
\hline 226,958 & 17 (1) & 225,329 & 17 (1) & 227,663 & 18 (1) & 226,323 & 17 (1) & \\
\hline 227,379 & 18 (1) & 225,378 & 17 (1) & 227,685 & 18 (1) & 226,328 & 20 (1) & \\
\hline 226,426 & 18 (1) & 226,591 & 18 (1) & 226,704 & 18 (1) & 227,525 & 18 (1) & \\
\hline 226,430 & 18 (1) & 226,608 & 18 (1) & 226,718 & 18 (1) & 227,569 & 19 (1) & \\
\hline 226,438 & 18 (1) & 226,616 & 18 (1) & 226,764 & 18 (1) & 227,868 & 18 (1) & \\
\hline 226,456 & 17 (1) & 226,688 & 18 (1) & 227,075 & 18 (1) & 227,901 & 18 (1) & \\
\hline 227,919 & 19 (1) & 228,301 & 18 (1) & 227,390 & 18 (1) & 229,129 & 18 (1) & Table Al \\
\hline 227,982 & 18 (1) & 228,303 & 18 (1) & 227,445 & $17(1)$ & 230,183 & $12(1)$ & ubjects taken and \\
\hline 227,983 & 18 (1) & 228,340 & 18 (1) & 228,273 & 19 (1) & 228,350 & 18 (1) & total subjects with \\
\hline \multicolumn{8}{|c|}{ Note: $n=140$ students } & reflective learning log \\
\hline
\end{tabular}


JRIT\&L

10,2

142

.

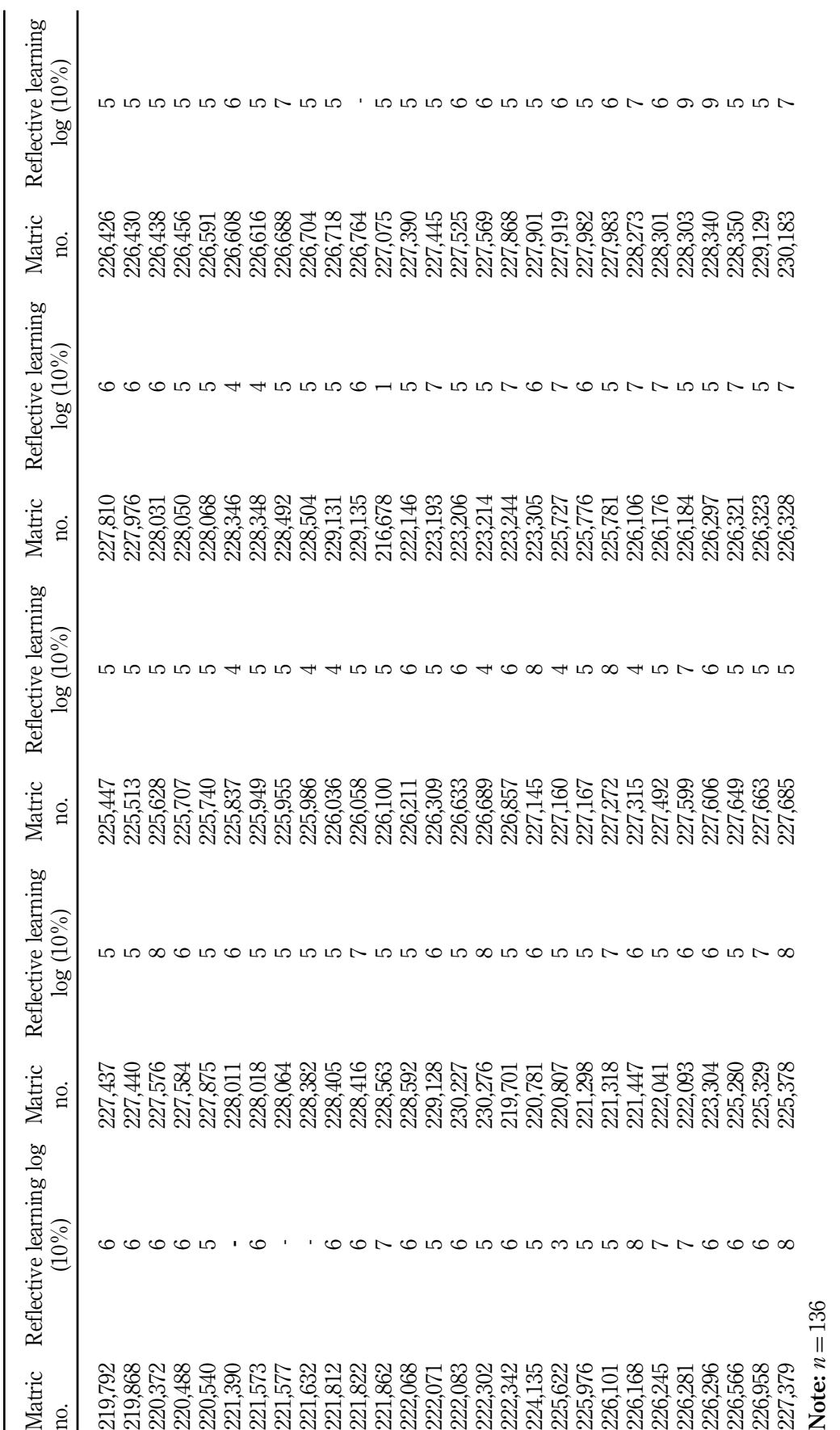

Table AII.

Mark sheets for reflective learning log (10 percent)

\section{Appendix 2}

